\title{
Abstraction and Artifice
}

Mark Southcombe, School of Architecture, Victoria University, Wellington

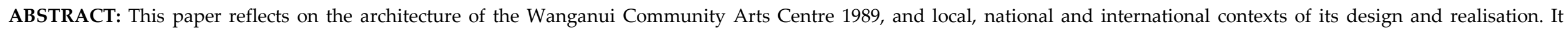

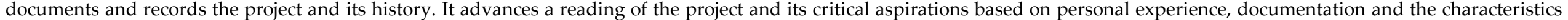
of the architecture. Finally, with reference to Jan Turnovsky's The Poetics of a Wall Projection implications of an architect writing history of architecture is reflected on.

Making a book is like making Architecture; you have to know at least something about the intractability of concrete things ${ }^{1}$

It is sobering when an annual history symposium covers a period that is close, a period that we have directly experienced, in which we have produced work. It invites reflection on history and our own relationship to it as it unfolds. This paper has been used as an opportunity to firstly document, and secondly reflect on aspects of a project I designed in the period, and potential relationships the architecture might generate to the historical record. What has been written about it? What can be determined about the architecture that is worthy of consideration? What effects has it had? And more generally how should architects write architectural history? This paper relies on evidence of architecture that may be discerned and discussed from the work itself, particularly in

\footnotetext{
${ }^{1}$ Turnovsky The Poetics of a Wall Projection inside cover.
}

relation to its physical, historical and cultural contexts. Following Jan Turnovsky ${ }^{2}$ I will adopt as method the idea that architecture has an empirical objective reality that contains traces of related conceptual material that may be critically discerned, interpreted and discussed directly from the work. I will examine the architecture in relation to its contexts primarily to document these, and to provide a basis for analysis and objective reinterpretation of the work that may begin to follow at the end of the text and at a later time by others.

\section{Contexts}

The international critique of modernism's abstraction and explorations of the introduction of meaning through surface and figuration that underpinned the emergence of architectural postmodernism were widely influential in New Zealand. The International Post Modern heros, such as James Stirling,

\footnotetext{
${ }^{2}$ Turnovsky The Poetics of a Wall Projection p 21.
}

Terry Farrell, Hans Hollein, Arata Isozaki, Michael Graves, Charles Moore and Stanley Tigerman, came to us through the periodicals such as Architectural Design $(A D)$ with its issues: Post Modern Classicism of 1980, Freestyle classicism 1982, Abstract representationalism 1983, Post modernisim and Discontinuity in 1987. The post modern fascination with surface was widely taken up in New Zealand throughout the country. Leading architects such as Miles Warren and Ian Athfield embraced the spirit and were designing projects such as 49 Boulcott Towers (1986), and the National Award winning skyline restaurant in Kelburn (1986).

The extent of the post modern influence in New Zealand was pervasive and extensive. It had co-incided with a period of unbridled prosperity and expansion, and, unlike later streams of international architectural thinking, post modernism was readily appreciated and adopted by architects, designers and the wider construction industry. It reached its 
low point with Chase Corporation projects in Auckland and Wellington ${ }^{3}$ and exemplified in a lecture to us as architectural students, by Seph Glew the managing director of Chase Corporation who took great delight in humiliating his architect John Sinclair in front of us. Glew described the unnecessary role of an architect, removed from all the critical decision-making, now made by a new breed of development experts, and with the architect's role being reduced to the superficiality of "clothing the building and documenting it for a fee of between 1 and 3\% of the project costs." 4 The major practices all did a trade in a New Zealand version of international postmodernism that they have since tried hard to forget. ${ }^{5}$ Every New Zealand city still has many post modern

${ }^{3}$ See Melling "The Mid-City Crisis" p 6.

${ }^{4}$ The presentation occurred in a professional practice lecture series at Auckland University co-ordinated by John Sutherland.

${ }^{5}$ For example, despite the quotation "Warren, its worth noting, may be the only architect in the country confident enough to readily own up to a post modern phase," the book New Territory: Warren and Mahoney is printed in white ink on a white page, and the book contains almost none of the extensive work completed by Warren and Mahoney in the 1980s and documented earlier in Warren and Mahoney Architects. Walker "Introduction" p 15. buildings. Even in the provinces.

Whanganui is a west coast North Island New Zealand small provincial city, population 45,000 . One of the oldest cities in New Zealand, it has a proud and noteworthy architectural heritage through most periods of New Zealand architectural history. With a few exceptions, such as the Rural Bank building by Structon Group, Whanganui architecture in the 1980s was dominated by the largest commercial practice of Dickson and Lonergan. Developer post modern best describes projects of the era such as Elders Pastoral offices (1986), and the Warnocks Head Office (1987). The practice also designed several remodellings of heritage building, such as the National Award winning Collegiate School Chapel extensions, but also several less sensitive and substantial Victorian façade remodels such as to the Victoria's Building in lower Victoria Avenue in what might be described as heritage post modern. These poor quality late provincial manifestations of eclectic postmodern classicism exemplified the thinness and all that was bankrupt in what had become an extensively adopted and superficially applied stylistic play. A mixed rhetoric around heritage had also become a glib supplement to support eclectic building with skin-deep design integrity.

When I moved to Whanganui in 1988 I noticed and was critical of this work. Filled with the naive confidence that came from a recent education and little experience, I conceptualised my design work as a demonstration of what was possible, an architectural critique through juxtaposition in time and space. The strength of the arts in Whanganui with the Sargeant Gallery, Summer schools of the Arts, and the Wanganui Regional Community Polytechnic, and its arts and craft focus particularly in ceramics, glass, painting, and printmaking, were also important local contexts for the design of the Wanganui Community Arts Centre project.

In the period before designing this project the architect, that's me, had been studying at architecture school graduating in 1987. It had been a period of transition at the Auckland school. I had experienced the last of the Brick integrated studio teaching of David Mitchell, Mike Austin, Sarah Treadwell, Kerry Morrow and Nick Stanish. I had come from a draughting background and so deliberately selected to study at Auckland, the stronger design school at the time. It was an exciting 
time. Paul Walker and Mark Wigley were completing their PhDs in competing schools of thought. Venturi's Complexity and Contradiction in Architecture, and Charles Jencks' The Language of Post-Modern Architecture were prescribed texts. Eisenman's "Post functionalism" of 1976, and "the end of the classical" of 1984, were key references for me. Daniel Libeskind's "Chamber works" exhibition (6-29 October 1983), and his "Three Lessons in Architecture" (1985) from the Venice Biennale, were also important. David Mitchell, practitioner and teacher, was my hero and role model. Mitchell's architecture at the time was squarely in the post modern camp, with projects such as the 1986 scheme for Housing New Zealand in Manukau City, a wrapping of the New Zealand state house in postmodern skin, and the National Award winning Gibbs House of 1986, notable projects of the time. My undergraduate thesis of 1986 investigated the importance and role of drawing, and argued for the primacy of the drawing, that architecture existed in drawing, regardless of whether it was built. I had worked for JaSMAD in holiday breaks on projects such as 210 Khyber Pass, but on graduation worked part-time at home in between being primary caregiver for our new son Luke. With my technical ability ${ }^{6}$ I had decided that I wanted to design my own work and not become a working drawing machine for other architects' creative outputs. Economically times quickly became extremely tough and we were earning less than when we were as students. With John McClean, I set up a practice based in Whanganui and undertook small alterations jobs, before eventually they led to bigger things.

In 1988, after an exchange of poetry, artist and member of the NZ crafts council, John W Scott, invited me to join a group of local artists at an annual general meeting of the Wanganui Community Arts Council, a meeting in which he effectively took over the council in a community arts coup d'état. At that meeting John was elected chairperson. He agreed to take on the role only if he was joined by a group of supportive people of action that would invest time and energy to achieve the

${ }^{6}$ I had worked as a draughtsman, but as evidence of the standard of my work I had been awarded the BRANZ award for excellence in the study of building technology at the end of 1982 and my NZCAD grades at the end of 1983 were sufficiently outstanding to prompt an effusive letter of invitation to study at Auckland from Allan Wild the Dean of the Auckland school. establishment of a full-time paid Community Arts Officer position and a Community Arts Centre facility.

A Community Arts officer position was soon established and we began searching for an appropriate existing warehouse facility to convert to an Arts centre soon after. I found what would become the site and building that was eventually purchased, and was a strong advocate for its qualities. It was a gritty former railways road services bus garage and depot in Taupo Quay. The area is in the oldest part of the city and at that time had predominantly manufacturing and industrial uses, occupying historic warehouses. I considered these to be a misuse of what was clearly the best part of the city, north facing, on the river's edge, close to the retail centre, and close to Queen's Park, and Moutoa Gardens, major historic passive recreation landscape reserves.

The site is on reclaimed land, originally the warehousing area of the city serviced by direct access from riverboats and coastal shipping using the river, and unloading on the edge of what became Moutua Quay on the river's edge side of the site. Wanganui Engineering workshops occupied a major part 
of the adjacent block, which also housed newspaper and commercial printing facilities, clothing factories, storage warehouses and a scrap metal yard.

The building on site had two parts constructed in different periods of time and did not have enough originality or architectural character to be considered an attractive proposition by most members of the Community Arts council. This was the context for the decision to locate the proposed Community Arts Centre. The Arts Council members' criticisms of the adjacent existing uses and the distance from retail centre was eventually overcome, the site purchased from Council, and the design of the project embarked on. The design to remodel the building occurred in mid 1988. The key architectural idea generating the design was that of a conversation between architecture and the arts. The project was to be constructed in stages over time as a series of community funded and constructed projects. The design initially presented was enthusiastically adopted without iteration or change, and was built very close to how it was originally designed over five major and several minor stages covering a 15 year period of time.
Initial projects included working bees to clean up the building, the filling in of the bus maintenance pits in the floors, and milling of macracarpa trees donated to help construct the project. Eventually funds were raised and the first stage consisting of a co-operative shop, a community gallery, a mezzanine floor and a gallery and shop storeroom were constructed and opened in September 1989.

The first stage began a conversation about composition, with the new in discussion with the old, and every element of the building being questioned in relation to a discussion between architecture and the arts. For example this discussion occurred within the geometry of the plan where the simple potential of a small $15^{\circ}$ shift in plan, was contrasted with the original orthogonal geometry. The $15^{\circ}$ shift explored in plan was also translated into the exterior composition within the glazing bars and surfaces of new walls. The design of the shopfront windows carries on this play of the new against the existing as a basis for a hybrid composition. For example what could and should a shopfront window be? The existing colonial glazed windows lines from the highlight windows were translated downwards as a basis for the new shopfront composition. The detail of the glazing of the two adjacent shopfront windows was played off against each other in asymmetrical balance. Glazing bars were carefully composed as visual elements within the composition. Opening window sashes and coloured glass with lead cames were direct glazed into the façade. When compared to conventional shopfront windows these can be seen to test explore the potential of what a shopfront window could become through its generation of an active, rather than neutral, aesthetic.

The next stage planned was a leatherworkers' studio, the new building stage on the street front of Taupo Quay beside the existing building, however there was no funding to realise it. As a move towards the new studio, the architecture was precursed with the design and construction of an outline of the building façade as a series of steel frames as a fence and gates. Like a built line drawing, representing the building to come, the design was drawn out against the space of the vehicle court behind it constructed as framed outline in rectangular steel sections, and reminiscent of the outline frame of Robert Venturi's Franklin Court, Philadelphia 1972-76, ${ }^{7}$ or the

${ }^{7}$ Jencks The Language of Post Modern Architecture p 89. 
gridded frames of Peter Eisenman's Wexner Centre for Visual Arts at Ohio State University. ${ }^{8}$ These white steel outline frames also functioned as a fence, securing the open space beside the building from the street. Soon after finance became available from the Leedstown Trust to build the studio represented by the frame. The soon to be redundant frame was way too beautiful to lose, and so we slid the studio siting backwards to enable the frame to remain permanently in place, proud of the building it represented. The building then materialised behind the frame, as if generated by it, and the frame remained like bones of a building somehow shifted outside the wall, its role now purely aesthetic. This was a delightful opportunity to extend our discussion of architecture and the arts, these elements conceptualised as a discussion of structure and building fabric.

The leatherworkers' studio was the new building on site, and its design continued the discussion with the original building. The design was carefully proportioned to create dialogue with the existing architectural orders

${ }^{8}$ Forster, Somer et al. "The Wexner centre for Visual Arts" pp 9-79. of the garage façade. Facing the street, the original composition was mirrored and distorted. Symmetry was disturbed. Compositionally the gable and proportions of the original were shifted to become a monopitch and flat roof. The figure/ground of the concrete frame was reversed complete with a black framed window introduced within the frame, and a mirrored glass window above the frame within the new half gable. Smooth materials were used contrasted with a heavy modeled roughcast plaster. Primary colours with complementary neutrals were applied in a manner where the colours were part of and accentuate the formal and surface composition.

The front façade turns an acute corner to become a concave curved solid side wall terminated by a deep vertical white timber screen. The curve hollows out an entrance space creating an entrance courtyard void, and directing movement towards the main side entry of the main building. The surface of the curved entry wall is modeled carefully with the materials and figure ground roughcast surface of the front façade. The surface here is however figured in an abstract manner. The $15^{\circ}$ shift of the front wall reappears here but it has been rotated, and stops short of the border, short of the edge of the frame, becoming a surface material division dividing the composition almost but not quite in two. The lack of completion of the compositional line calls attention to itself and invites further investigation. What's going on here? What is going on is made clearer by the complementary application of colour. The colour of the incomplete line changes over its length. From the grey of the frame at the top it changes gradually to a dark blue dividing strip at the bottom. Then it stops. The graduated line divides a curved surface that is also graduated in colour - from the neutral beige of the original façade frame to the positive primary yellow of the new composition. Influenced by lecturer David Mitchell's University of Auckland Music School, which employed graduated colour on its exterior wall curved surface, this project adapts the idea of an architectural wall that changes colour and extends it. The result is an architectural wall that begins to operate in the manner of an abstract painting. Through the addition of "a line more reminiscent of a canvas than a wall"9 questions regarding the treatment of architectural wall surfaces are prompted. Why shouldn't wall colour be

\footnotetext{
9 "Primarily Arts" pp 162-163.
} 
graduated like it might be in an abstract painting? Why shouldn't a wall surface composition be considered like it might be if it was framed?

The leatherworkers' studio is linked to the existing building canopy with a new pergola forming a gable shape, but with a twist. "Overhead a pergola follows the curve of a wall with its end hanging free in space."10 There is an extended bay window door structure below and forming the entrance canopy. The $15^{\circ}$ shift reoccurs here in two directions within the top of the entrance bay window, and also within the glazing bars.

Formally the studio façade is more than skin deep. The asymmetrical duality of the street façade composition is extruded through the building. Craft becomes the dominant concern within the space. Tectonic details become the site of exploration through the critical structural moments where the supporting beam is in turn supported, and celebrated. There is a redundancy created within the structure that makes the play with structure and detail explicit. Here the way the building is made is the basis for its architectural

10 "Primarily Arts" pp 162-163. expression. The timbers used are rubbed in Danish oils giving them a patina and aroma that contributes a particular spatial character. Where the studio meets the major exterior courtyard space the exterior surfaces change. No longer plaster, the walls are constructed from a natural weathered cedar cladding, under a sheltering small-scaled verandah structure, contributing a crafted edge to a earthy paved courtyard space.

The potters' studio was the third major stage, and it continued the implementation of the original master plan. The extent of new space created was maximised between the four edge limits of the exterior courtyard, the north site boundary, the existing building, and existing service access. The edge of the new studio defines and completes the key exterior space, a substantially enclosed courtyard continuing the simple craft based aesthetic established in the design of the rear of the stage two potters studio. The significant formal move of the stage was the introduction of a curved roof to mediate between a formal extrusion of the front stage half gable along the boundary wall against the adjacent building, all completed with attention to craft in the manner of the leatherworkers' studio. The face of the potters' studio carries around a narrow rusticated cedar boarded treatment of the rear of the leatherworkers studio completing the courtyard with a less formal and self conscious aesthetic treatment as a deliberately more informal space. Raised planters faced with purpose made unglazed terracotta tiles, and paving extends the $15^{\circ}$ shift through the paved surfaces to complete and activate the courtyard composition. This paving also extends into and through the adjacent entry courtyard and the footpath adjacent.

Many other minor stages of work also occurred, the sunscreens and deferred maintenance, upgrading toilets, and common room areas, reroofing. The final major stage occurred some 13 years later with the workshop, senior net area, and upper room mezzanine floor. This addition followed the original design in the manner of a master plan. Spatially the pattern had been set although uses originally anticipated had changed. A second major interior workshop and gallery volume was formed with a new upper room extension and space below at the rear of the building for senior computer users. This stage was significant as it reoriented parts of the project to face the Whanganui River rather than the street, and formalised a second frontage facing the river. Aesthetically 
this stage of the design began to modify the existing river's edge façade by the addition of a tall projecting bay window box suspended over the road edge below, and extending and terminating a new gable roof behind. Like the front façade, the rear composition was derived from a conversation with the existing building aesthetics. The original framed structure was evident partially infilled with brickwork and with windows composed as holes within the frames. The asymmetrical composition was accentuated by extending the gable towards the river and terminating it with the bulk of the bay window. Cedar was used as cladding in narrow boards integrating the crafted timber with the more formal and structured solid composition of the existing. An upper meeting and work room formed by extending the roof space towards the river has expansive views of the rivers edge and river. The road surface was also paved extending the presence of the now more formal front, and anticipating a future where doors will be inserted below the bay window and a public use and activity will spill out onto the river's edge.

The project was not well received by local architects. Several architects attended the opening, yet only one, retired architect Ron
Lamont took the opportunity to speak with me about it. "Well done" he said. "Lots of white walls and polished floors. You can't go too far wrong there." The project was also my first submission for a NZIA Western Branch Award and it was not selected for one. Architect Tony Baker, the jury chairman, confided in me at the awards event, where the awards were announced, that the project "caused heated debate among the jury," and also that it was "problematic," but he was unable or unwilling to discuss how. New Zealand Home and Building published an article "Primarily Arts" on the project in 1993. The Arts Centre was later adopted as the Whanganui venue for the exhibition of NZIA awards for architecture in years that its gallery space was available.

The Community Arts Centre was extremely well received locally and well supported by local artists beginning with a selected exhibition titled "Wanganui's best." It has for 20 years facilitated the development of the community arts by giving a ready access gallery space for emerging artists, education and meeting spaces, arts administration offices, a co-operative retail outlet, studios and workshop spaces. The gallery space is booked on a weekly basis and requires booking ahead by about a year. The entire project was funded from donations and through support from community trusts. Recently it was controversially repainted pink and purple, and had signage fixed to the front of the leatherworkers' studio.

The wider urban context around the arts centre has changed dramatically over the 20 years since the Arts Centre was established. There is no longer any industrial uses in the area. The establishment of Quay School of the Arts, opposite the Community Arts Centre, in 1993 was an important change. This was later redeveloped as the site of a relocated, rationalised, entire polytechnic in 2007. Several tourist-related uses, complementary to the Community Arts Centre, such as the Riverboat Museum, the tram barn museum, and the Rivercity Traders markets, have also been established in the area. The river's edge has also been redeveloped as a passive recreational area complete with boardwalk and promenade. The Arts Centre is now the centerpiece of an arts culture and tourism precinct.

So returning to our initial question: What can be determined from the descriptive and contextual material on the Community Arts 
Centre and contexts of its design now elaborated? What can be found from an examination of the evidence of architecture regarding the historicity of the building, and critical reflection on this contaminated process of architect writing about their own architecture? What reflections can be made about the implications of an architect writing architectural history?

Clearly my multiple roles as architect, theoretician, historian, and author threaten to collapse critical space. The idea of a practicing architect writing on their own work is regarded by most academics as inherently problematic. Academic and VUW FoAD Associate Dean Research Robin Skinner cheekily describes the architects writing on their own work as "puff pieces,"11 somehow inherently problematic, without the necessary critical rigour and space needed for critical history. This was also the theme of Joan Kerr's polemic paper for the 1984 SAHANZ conference: "Why Architects should not write Architectural History."12 The proposition is

${ }^{11}$ Robin Skinner used the term "puff pieces" as a general description of the writing of practicing architects about their work when I applied for research funding to document this building.

${ }^{12}$ Kerr "Why Architects should not write Architectural that the architect is compromised by their familiarity with the work, by the directness of their knowledge of the work and the manner it came to be and operates on its environment; that an architect is unable to reflect critically on their work and contextualise it in the manner of a historian. There is also the related issue of literary expertise, and perhaps an academic demarcation of territory, an argument for those with an expertise in history to write it. At the root of this is a discussion regarding the authority of the author, the claim the author may make for authority of origins that is not available to the historian. Certainly the inside knowledge and existing familiarity with the characteristics and circumstances of a project helps point the way as a text is constructed, but this privileged information can be also be checked against external contexts. An historian's critique may also potentially be more influential. Historians define, interpret and document history, they write, record and authorise history. Their work is removed from the subject and therefore regarded as more impartial, yet it is as influenced and compromised by the contexts of its production. For the purposes of this paper an

History" pp 23-31. author's interpretation of a work is accepted as being as valid as anyone else's and that this is a good place to start. So how do you write critically on your own work, working from the work? or on the work, reworking, reinscribing it, contextualising, and opening it up to critical examination? Clearly this requires the clear framing and contextualising of the work. For this text, a critical frame that this critique may be viewed through is the context of my ongoing research into the building as evidence of critical (or not) enquiry and demonstration of argument via a built mode of representation; ${ }^{13}$ the argument for the power of building to carry ideas. In this context direct examination the Whanganui Community Arts Centre's architecture has provided the method to construct and order this paper; building considered as primary reference material containing evidence of critical activity.

The Whanganui Community Arts Centre is as good an example as any of the richness and complexity of built, constructed architecture. We have hardly scratched the surface of what can be observed and determined from the work and its contexts for anyone who

\footnotetext{
${ }^{13}$ See Southcombe "Silent Voices" n.p.
} 
examines a work, who looks closely at it. We have yet to examine its local effects, which might be argued to have been significant in some ways certainly from an urban perspective, and we have yet to consider the potential of relationships of this project to other work by myself that follows it. These considerations will await further work by others, that can now build on this textural foundation. The bigger question is why would we look more closely at any work or at any aspect of a work? In this case my argument is that this particular example of New Zealand architecture has not yet been contextualised when compared with other architecture of this period, and that through examination of the rigor and depth of its investigation, testing and application of abstract syntactical compositional ideas comparisons might be made. The architecture is clearly operating as a critical exploration of problems and potentials of a post modern concern with abstracted meaning in a manner few other New Zealand buildings, I am aware of, do. This occurs through the evident characteristics of the architecture that can be determined from its experience or reflection on its representations. Returning to the question of an architect writing about architecture the key question that has been distilled is to do with interpretations and perception, what might be described as an internal verses external frame of reference, This is discussed by Turnovsky:

The internal aesthetic structure is an unreliable gauge for an artwork since (in part at least) it only comes into being when the work is perceived by an individual. The criterion of external limitation or embrasure, by comparison, is much more robust and objective, since it is hardly susceptible to any interpretative vacillations We are referring here to that rhetorical index, either real or imagined, that prompts an aesthetically oriented interpretation of a given object ${ }^{14}$

This text on the Whanganui Community Arts Centre might be regarded as a frame in the manner of Turnovskys discussion of Art and Frame, ${ }^{15}$ and can be seen to have focused attention on this project, to have framed it for aesthetic consideration, and for potential (re)consideration of its aesthetic potential and effects.

${ }^{14}$ Turnovsky The Poetics of a Wall Projection $\mathrm{p} 119$.

15 Turnovsky The Poetics of a Wall Projection $\mathrm{p} 118$. 


\section{REFERENCES}

Eisenman, Peter "Post functionalism" Oppositions (Fall 1976) 6:[1]-[3].

Forster, Kurt Walter, Robert E. Somer et al. "The Wexner Center for Visual Arts" Architectural Design (1989) 11/12:[1]-80.

Jencks, Charles, The Language of Post Modern Architecture, London: Academy Editions, 1984; first published 1977.

Kerr Joan "Why Architects should not write Architectural History" (1984) Shifting Views; Selected Essays on the Architectural History of Australia and New Zealand ed Andrew Leach, Antony Moulis \& Nicole Sully, Brisbane: University of Queensland Press, 2008:23-31.

Melling Gerald "The Mid-City Crisis" The Mid-City Crisis and other stories Wellington: Thumbprint Press, 1989:6-11.

"Primarily Arts" Home and Building (December 1992/January 1993):162163.

Southcombe, Mark "Silent Voices" Cultural Crossroads, proceedings of the $26^{\text {th }}$ International SAHANZ Conference ed. Julia Gatley, Auckland: Auckland University, 2009, CD ROM

Turnovsky, Jan The Poetics of a Wall Projection London: AA Publications, 2009.

Venturi, Robert Complexity and Contradiction in Architecture New York: Musuem of Modern Art, 1966.

Walker Paul "Introduction" New Territory: Warren and Mahoney: 50 years of New Zealand architecture Auckland: Balassoglou books, 2005:12-15.

Warren and Mahoney Architects, 1958-1989 Christchurch [N.Z.]: The Architects,1989. 